\title{
Analisis Nilai Tambah Usaha Pengolahan Ikan Belida Menjadi Kerupuk Di Kelurahan Kemalaraja Kecamatan Baturaja Timur Kabupaten OKU
}

\author{
Ary Eko Prastya Putra \\ Sekolah Tinggi Ilmu Pertanian Belitang \\ Jln.Kampus Pertanian No.3 Belitang Kab.OKU Timur Prov.Sumatera Selatan \\ e-mail: ary.speed88@gmail.com
}

\begin{abstract}
The objectives of this study were to: 1) determine the amount of income obtained from processing belida fish into crackers in Kemalaraja Village, East Baturaja District, OKU Regency, 2) determine the amount of added value obtained from processing belida fish into crackers in Kemalaraja Village, East Baturaja District, Regency OKU. The results showed that the income obtained in the business of processing belida fish into crackers in Kemalaraja Village, East Baturaja District, OKU Regency is Rp. 549,288 / average production, while the added value generated in the business of processing belida fish into crackers in Kemalaraja Village, East Baturaja District, Regency OKU is IDR 627,465 / production average, and the added value per $\mathrm{kg}$ is IDR 38,128.
\end{abstract}

Key Word : Value-added, entrepreneurial theory, home industry

\section{PENDAHULUAN}

\section{A. Latar Belakang}

Indonesia merupakan negara kepulauan yang sebagian besar luas wilayahnya merupakan perairan. Ikan merupakan salah satu hasil perikanan yang banyak dihasilkan di Indonesia dan merupakan sumber protein hewani yang banyak dikonsumsi masyarakat. Ikan mudah didapat dengan harga yang relatif murah sehingga dapat dijangkau oleh semua lapisan masyarakat. Kandungan pprotein yang tinggi yaitu $17,00 \%$ dan kadar lemak yaitu 4,50\% yang rendah pada ikan segar sangat bermanfaat bagi kesehatan tubuh manusia. Hasil perikanan bersifat mudah rusak sehingga tingkat kehilangan atau kerusakan pascapanen relatif lebih tinggi dibandingkan dengan bahan pangan lainnya, oleh karena itu, peningkatan produk perikanan harus diimbangi dengan penaganan pascapanen dan teknologi pengolahan yang memadai. Banyak jenis ikan di Indonesia yang belum dimanfaatkan secara optimal. Beberapa jenis ikan tersebut mempunyai prospek yang baik untuk diolah, salah satunya adalah ikan belida (Anonim, 2005).

Ikan hasil pengolahan dan pengawetan umumnya sangat disukai oleh masyarakat karena produk akhirnya mempunyai ciri-ciri khusus yakni perubahan sifat-sifat daging seperti bau (odour), rasa (flavour), bentuk (appearance) dan tekstur.

Salah satu makanan hasil olahan dari ikan adalah kerupuk ikan. Produk makanan kering dengan bahan baku ikan dicampur dengan tepung tapioka ini sangat digemari masyarakat. Makanan ini sering digunakan sebagai pelengkap ketika bersantap ataupun sebagai makanan ringan. Bahkan untuk jenis makanan khas tertentu selalu dilengkapi dengan kerupuk. Makanan ini menjadi kegemaran masyarakat dikarenakan rasanya yang enak, gurih dan ringan.

Tabel. 1 Kandungan Gizi Ikan Belida per 100gr

\begin{tabular}{|c|c|c|c|}
\hline No & Komposisi & $\begin{array}{c}\text { Jumlah } \\
\text { Kandungan }\end{array}$ & Satuan \\
\hline 1 & Kalori & 120 & (kkal) \\
\hline 2 & Protein & 16,5 & (g) \\
\hline 3 & Lemak & 5,3 & (g) \\
\hline 4 & Karbohidrat & 0,4 & $(\mathrm{~g})$ \\
\hline 5 & Kalsium & 52 & $(\mathrm{mg})$ \\
\hline 6 & Fosfor & 216 & $(\mathrm{mg})$ \\
\hline 7 & Zat Besi & 1,1 & (g) \\
\hline 8 & Vitamin A & 233 & $\mathrm{~A}(\mathrm{SI})$ \\
\hline 9 & Vitamin B1 & 0,1 & $\mathrm{~B} 1$ (mg) \\
\hline 10 & Vitamin C & 0 & $\mathrm{C}(\mathrm{mg})$ \\
\hline
\end{tabular}
nilai yang terjadi karena adanya perlakuan terhadap suatu input pada suatu proses produksi. Arus peningkatan nilai tambah komodutas pertanian terjadi di setiap mata rantai pasok dari hulu ke hilir berawal dari petani dan berakhir pada konsumen akhir. Nilai tambah komoditas pertanian di sektor hulu dapat dilakukan dengan penyediaan bahan baku berkualitas dan berkesinambungan yang melibatkan para pelaku mata rantai pertama. Nilai tambah pada sektor hilir melibatkan industri pengolahan. Komoditas pertanian yang bersifat perishable (mudah rusak) dan bulky (kamba) memerlukan penanganan yang tepat, sehingga produk pertanian siap dikonsumsi oleh konsumen. Perilaku tersebut antara lain pengolahan, pengemasan, pengawetan, dan manajemen mutu untuk menambah kegunaan menimbulkan nilai tambah sehingga harga produk pertanian menjadi tinggi (Marimin dan Magfiroh, 2010).

Pengolahan ikan belida menjadi kerupuk ikan belida adalah salah satu bentuk nilai tambah yang mengubah bentuk dari produk primer menjadi produk 
baru yang lebih tinggi nilai ekonomisnya setelah melalui proses produksi, sehingga terbentuk harga baru yang lebih tinggi dan keuntungan yang lebih besar bila dibandingkan tanpa melalui proses produksi. Yaitu dari $3 \mathrm{~kg}$ ikan belida dicampur dengan bahan lainya, setelah diolah akan menjadi 6kg produk kerupuk.

Ikan belida juga termasuk ikan yang sudah jarang ditemui dan berbagai produk olahanya seperti pempek dan kerupuk pun banyak yang sudah digantikan dengan ikan laut dan ikan tenggiri, dan masyarakat pun akan tetap membeli olahan produk ikan belida (kerupuk) walaupun harganya sedikit lebih mahal daripada kerupuk ikan biasanya karena memang kerupuk yang berasal dari ikan belida asli akan berbeda rasanya dengan kerupuk ikan lainya meskipun namanya dinamai dengan kerupuk ikan belida.

\section{B. Rumusan Masalah}

Berdasarkan latar belakang dan uraian di atas, adapun permasalahan yang menarik untuk diteliti adalah sebagai berikut :

1. Berapa besar pendapatan yang diperoleh dari pengolahan ikan belida menjadi kerupuk di Kelurahan Kemalaraja Kecamatan Baturaja Timur Kabupaten OKU?

2. Berapa besar nilai tambah yang diperoleh dari pengolahan ikan belida menjadi kerupuk di Kelurahan Kemalaraja di Kecamatan Baturaja Timur Kabupaten OKU?

\section{Tujuan dan Kegunaan}

Berdasarkan rumusan masalah yang telah dijabarkan, maka secara umum penelitian ini bertujuan untuk :

1. Untuk mengetahui besarnya pendapatan yang diperoleh dari pengolahan ikan belida menjadi kerupuk di Kelurahan Kemalaraja Kecamatan Baturaja Timur Kabupaten OKU

2. Untuk mengetahui besarnya nilai tambah yang diperoleh dari pengolahan ikan belida menjadi kerupuk di Kelurahan Kemalaraja Kecamatan Baturaja Timur Kabupaten OKU

Hasil penelitian ini diharapkan menjadi bahan informasi dan manfaat bagi pihak-pihak berkepentingan dalam bidang pengolahan ikan belida menjadi kerupuk ikan belida. Selain itu, hasil ini juga diharapkan dapat menjadi bahan referensi untuk penelitian selanjutnya dan sebagai pustaka ilmiah

\section{KERANGKA PEMIKIRAN}

\section{A. Model Pendekatan}

Berdasarkan kajian kepustakaan tersimpul bahwa nilai tambah adalah kegiatan atau langkahlangkah dalam proses yang menambah atau mengubah suatu produk atau jasa. Komuditas pertanian pada umumnya mempunyai sifat mudah rusak sehingga perlu langsung dikonsumsi atau dioleh terlebih dahulu. Proses pengolahan yang disebut agroindustri dapat meningkatkan guna bentuk komuditas pertanian. Konsumen yang bersedia membayar output agroindustri dengan harga yang relatif tinggi merupakan insentif bagi perusahaan pengolah. Kegiatan agroindustri yang dapat meningkatkan nilai tambah komuditas pertanian dalam operasionalnya membutuhkan biaya pengolahan. Salah satu konsep yang sering digunakan untuk membahas biaya pengolahan hasil pertanian adalah nilai tambah. Faktorfaktor yang mempengaruhi nilai tambah pengolahan dapat dikategorikan menjadi dua yaitu faktor teknis dan faktor pasar. Faktor teknos yang mempengaruhi adalah kapasitas produksi, jumlah bahan baku yang digunakan dan tenaga kerja. Faktor pasar ayng mempengaruhi harga output, upah tenaga kerja, harga bahan baku dan nilai input lain selain bahan baku dan tenaga kerja (Sjarkowi dan Marwan, 2004).

Besarnaya nilai tambah karena proses pengolahan didapat dari pengurangan biaya bahan baku dan input lain terhadap nilai produk yang dihasilkan, tidak termasuk tenaga kerja. Dengan kata lain nilai tambah menggambarkan imbalan bagi tenaga kerja (Wastono, 2004).

Distribusi nilai tambah berhubungan dengan teknologi yang diterapkan dalam proses pengolahan, kualitas tenaga kerja berupa keahlian dan ketrampilan serta kualitas bahan baku. Penerapan teknologi yang cenderung padat karya yang akan memberikan proporsi bagian keuntungan bagi perusahaan, sedangkan apabila yang diterapkan teknologi padat modal, maka besarnya proporsi bagian perusahaan lebih besar dari pada proporsi bagian tenaga kerja (Wastono, 2004).

Secara ekonomis, peningkatan nilai tambah suatu barang dapat dilakukan melalui perubahan bentuk (from utility) suatu produk akan mempunyai nilai tambah ketika barang tersebut mengalami perubahan bentuk. Misal ikan belida berubah menjadi kerupuk. Melalui perubahan tempat (Place utility) suatu barang akan memperoleh nilai tambah apabila barang tersebut mengalami pindah tempat, misalnya ikan belida ketika biasanya didesa hanya dimanfaatkan sebagai lauk, ketika melalui pengolahan maka bisa menjadi kerupuk (Malisi, 2016).

Faktor-faktor yang mempengaruhi nilai tambah pengolahan dapat dikategorikan menjadi dua yaitu faktor teknis dan faktor pasar. Faktor teknis yang mempengaruhi adalah kapasitas produksi, jumlah bahan baku yang digunakan dan tenaga kerja. Faktor pasar ayng mempengaruhi harga output, upah tenaga kerja, harga bahan baku dan nilai input lain selain bahan baku dan tenaga kerja. Besarnya nilai tambah dipengaruhi proses pengolahan yang didapat dari pengurangan biaya bahan baku dan input lain terhadap nilai produk yang dihasikan (Fitriah, 2015).

Arahan konseptual dan asumsi-asumsi yang terkandung dalam uraian di atas memungkinkan tersususunnya suatu kerangka berfikir model pendekatan diagramatis. 


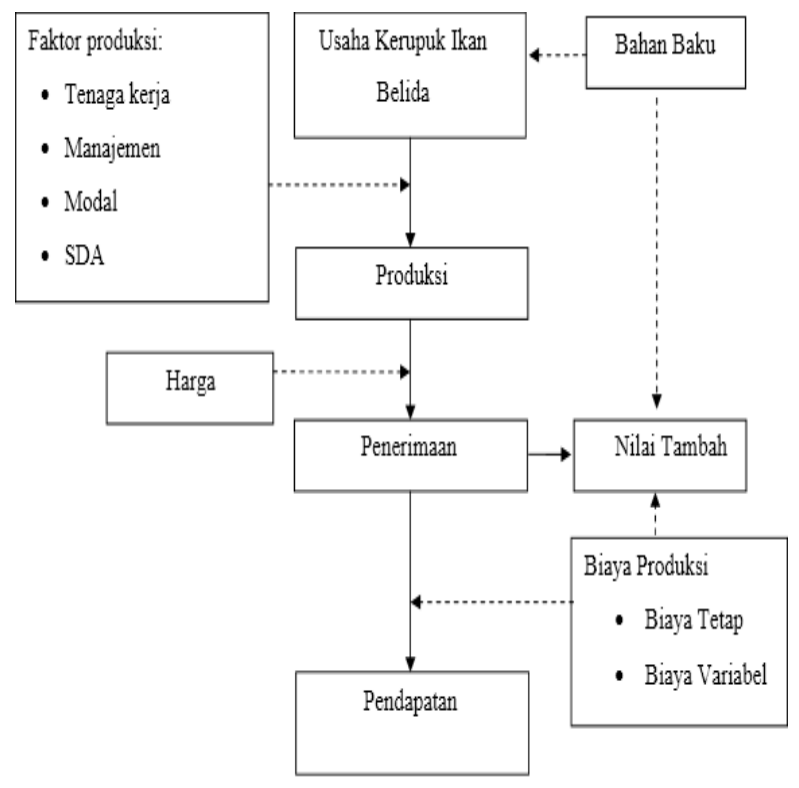

Keterangan:

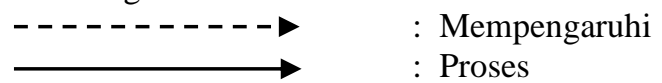

Gambar 1. Model Pendekatan Diagramatis pada Usaha Pengolahan Kerupuk

Sedangakan secara matematis dapat dilihat sebagai berikut :

1) Untuk menghitung biaya produksi (Soekartawi, 2002), digunakan rumus:

$\mathrm{TC}=\mathrm{VC}+\mathrm{FC}$

\section{Dimana}

TC $=$ Total Cost $/$ Total Biaya Produksi

$\mathrm{VC}=$ Variabel Cost/Biaya Tidak Tetap

$\mathrm{FC}=$ Fiex Cost/Biaya Tetap

2) Untuk menghitung penerimaan (Soekartawi, 2002), digunakan rumus:

$\mathrm{R}=\mathrm{Y} \times \mathrm{P}$

Dimana

$\mathrm{R}=$ Revenius $/$ Penerimaan $(\mathrm{Rp})$

$\mathrm{Y}=$ Yeild/ Output Produksi $(\mathrm{Kg})$

$\mathrm{P}=$ Price/ Harga $(\mathrm{Rp} / \mathrm{Kg})$

3) Untuk menghitung pendapatan (Soekartawi, 2002), digunakan rumus:

$\mathrm{I}=\mathrm{R}-\mathrm{TC}$

Dimana

$\mathrm{I}$ = Income/Pendapatan

$\mathrm{R}=$ Revenius $/$ Penerimaan

$\mathrm{TC}=$ Total Cost/Total Biaya Produksi

3) Untuk menghitung nilai tambah (Yudi, 2010) digunakan rumus:

$\mathrm{AV}=\mathrm{TR}-\mathrm{IC}$.

Dimana :

$\mathrm{AV}=$ Added Value/ Nilai Tambah

$\mathrm{TR}=$ Total Revenue/ Total Penerimaan

$\mathrm{IC}=$ Interediate Cost/ Biaya Antara (biaya produksi - tenaga kerja keluarga)

\section{B. Hipotesis}

Berdasarkan tujuan penelitian di atas, maka dapat ditarik suatu hipotesis dalam penelitian ini adalah sebagai berikut:

1. Bahwa biaya produksi pada usaha pengolahan ikan belida menjadi kerupuk di Kelurahan Kemalaraja Kecamatan Baturaja Timur Kabupaten OKU lebih kecil daripada nilai produksi sehingga diperoleh pendapatan.

2. Bahwa usaha pengolahan ikan belida menjadi kerupuk di Kelurahan Kemalaraja Kecamatan Baturaja Timur Kabupaten OKU memiliki nilai tambah.

\section{Batasan-Batasan}

1. Responden adalah pelaku home industri pengolahan kerupuk ikan belida di Kelurahan Kemalaraja Kecamatan Baturaja Timur Kabupaten OKU

2. Ikan belida adalah bahan baku utama tambahan untuk penguat rasa dalam pengolahan kerupuk ikan belida.

3. Kerupuk ikan belida adalah jenis makanan yang berbentuk cemilan renyah yang diproses dengan penggorengan dengan bahan baku terigu serta bahan tambahan ikan belidadan bahan lainya.

4. Produksi adalah jumlah produk yang dihasilkan oleh responden berupa kerupuk ikan dengan satuan (Kg/pp).

5. Faktor produksi adalah sumber daya yang digunakan dalam proses produksi Kerupuk ikan belida.

6. Harga adalah nilai jual dari kerupuk ikan belida yang ditetapkan oleh responden pada saat penelitian $(\mathrm{Rp} / \mathrm{Kg})$.

7. Biaya produksi adalah total biaya yang dikeluarkan dalam satu kali proses produksi yang meliputi biaya tetap dan biaya veriabel (Rp/PP).

8. Modal adalah sesuatu yang digunakan untuk mendirikan atau menjalankan suatu usaha, modal bisa berupa uang atau tenaga kerja (keahlian).

9. Tenaga kerja pengolahan ikan belida menjadi kerupuk ikan belida adalah tenaga kerja keluarga.

10. Sumber daya alam (SDA) adalah sesuatu yang dapat dimanfaatkan untuk berbagai kepentingan dan kebutuhan hidup manusia agar hidup lebih sejahtera.

11. Biaya variabel adalah biaya yang jumlahnya tergantung dari besarnya jumlah produksi serta habis dalam satu kali proses produksi (Rp/PP).

12. Biaya tetap adalah biaya yang jumlahnya tidak tergantung dari jumlah produksi dan biaya besar kecilnya tidak dipengaruhi oleh jumlah produksi(Rp/PP).

13. Penerimaan adalah jumlah dari hasil produksi $(\mathrm{Kg} / \mathrm{pp})$ yang diperoleh home industri dikalikan harga( $\mathrm{Rp} / \mathrm{kg})$ pada saat penelitian (Rp/PP).

14. Pendapatan atau keuntungan adalah jumlah uang yang diterima oleh pelaku home industri ikan belida dari penerimaan yang telah dikurangi biaya produksi $(\mathrm{Rp} / \mathrm{PP})$.. 
15. Agribisnis adalah kegiatan usaha dibidang pertanian yang komersil baik dari sektor in-put, proses, maupun output dengan tujuan untuk mendapatkan keuntungan secara maksimal.

16. Usaha pengolahan adalah kegiatan pengolahan suatu produk hasil pertanian primer untuk menjadi bahan baku dari suatu olahan lanjutan.

17. Nilai tambah adalah selisih antara nilai output yang dihasilkan dengan biaya antara bahan baku ( Rp/kg).

18. Biaya antara adalah biaya yang dikeluarkan dalam proses produksi seperti bahan baku input lainya kecuali tenaga kerja keluarga.

\section{PELAKSANAAN PENELITIAN}

\section{A. Tempat dan Waktu}

Penelitian ini dilaksanakan di Kelurahan Kemalaraja Kecamatan Baturaja Timur di Kabupaten OKU. Penentuan lokasi ini dilakuakn secara purposive sampling (sengaja) dengan menggunakan metode studi kasus. Dikarenakan di kelurahan tersebut adalah salah satu tempat pengolahan di Kabupaten OKU. Sedangkan penelitian ini dilaksanakan pada Bulan Januari 2019 sampai Bulan Maret 2019.

\section{B. Metode Penelitian}

Metode penelitian yang digunakan dalam penelitian adalah metode studi kasus. Menurut Walgito (2010), menyatakan bahwa studi kasus merupakan suatu metode untuk menyelidiki atau mempelajari suatu suatu kejadian mengenai perseorangan atau suatu usaha. Sampel dalam penelitian ini yaitu home industri yang berada di Kelurahan Kemalaraja Kecamatan Baturaja Timur Kabupaten OKU.

Menurut Sugiyono (2012), menyatakan sampling jenuh (sensus) adalah teknik penentuan sampel apabila semua anggota populasi digunakan sebagai sampel. Dalam hal ini responden pengolahan kerupuk ikan belida adalah responden satu-satunya.

\section{Metode Pengumpulan Data}

Metode pengumpulan data yang digunakan dalam penelitian ini adalah dengan menggunakan metode observasi langsung dan wawancara yang dilakukan dengan cara pengambilan data primer dan sekunder melalui pengisian daftar pertanyaan yang menggunakan quisioner dan wawancara langsung dengan responden.

Menurut Suharsimi (2002), mengatakan bahwa metode wawancara adalah metode yang digunakan untuk mendapatkan informasi dengan melalui tanya jawab terhadap responden dengan mengumpulkan data-data baik data primer maupun data sekunder. Data primer bersumber dari hasil wawancara dengan pelaku usaha dan pengamat dilapangan, sedangkan data sekunder diperoleh dari referensi buku, internet dan lain-lain.

\section{Metode Pengolahan Data}

Data yang dikumpulkan meliputi data primer dan data sekunder. Pengumpulan data primer diperoleh dari wawancara langsung dengan narasumber menggunakan daftar pertanyaan (Quisioner) yang telah disiapkan penulis. Sedangkan data sekunder diperoleh dari terkait yang terhubung dengan peneliteratur, baik dari wabsite internet, maupun dari literatur perpustakkan.

1. Untuk menjawab tujuan pertama yaitu untuk mengetahui besarnya pendapatan yang diperoleh dari pengolahan ikan belida menjadi kerupuk di Kelurahan Kemalaraja Kecamatan Baturaja Timur Kabupaten OKU menggunakan rumus sebagai berikut:

a.Untuk menghitung biaya produksi (Soekartawi, 2002), digunakan rumus:

$\mathrm{TC}=\mathrm{VC}+\mathrm{FC}$

Dimana :

$\mathrm{TC}=$ Total Cost/Total Biaya Produksi (Rp)

$\mathrm{VC}=$ Variabel Cost/Biaya Tidak Tetap (Rp)

$\mathrm{FC}=$ Fixed Cost/Biaya Tetap (Rp)

b. Untuk menghitung penerimaan (Soekartawi, 2002), digunakan rumus:

$\mathrm{R}=\mathrm{Y} \times \mathrm{P}$

Dimana :

$\mathrm{R}=$ Revenius $/$ Penerimaan $(\mathrm{Rp})$

$\mathrm{Y}=$ Yeild/ Output Produksi (Kg)

$\mathrm{P}=$ Price/ Harga $(\mathrm{Rp} / \mathrm{Kg})$

c.Untuk menghitung pendapatan (Soekartawi, 2002), digunakan rumus:

$\mathrm{I}=\mathrm{R}-\mathrm{TC}$

Dimana :

I = Income/Pendapatan ( Rp)

$\mathrm{R}=$ Revenius $/$ Penerimaan $(\mathrm{Rp})$

$\mathrm{TC}=$ Total Cost/Total Biaya Produksi (Rp)

2. Untuk menjawab tujuan kedua yaitu untuk mengetahui besarnya nilai tambah yang diperoleh dari pengolahan ikan belida menjadi kerupuk di Kelurahan Kemalaraja Kecamatan Baturaja Timur Kabupaten OKU menggunakan rumus sebagai berikut:

Untuk menghitung nilai tambah (Yudi, 2010) digunakan rumus:

$\mathrm{AV}=\mathrm{TR}-\mathrm{IC}$

Dimana :

$\mathrm{AV}=$ Added Value/ Nilai Tambah

$\mathrm{TR}=$ Total Revenue/ Total Penerimaan

$\mathrm{IC}=$ Interediate Cost/ Biaya Antara

(biaya produksi - tenaga kerja keluarga)

\section{HASIL DAN PEMBAHASAN}

\section{A. Biaya Produksi Usaha Pengolahan Ikan Belida Menjadi Kerupuk}


Biaya produksi (total cost) yang ada dalam usaha pengolahan kerupuk ikan belida terdiri dari jumlah biaya tetap dan biaya variabel.

Tabel 2. Total Biaya Produksi pada pembuatan kerupuk ikan belida.

\begin{tabular}{clr}
\hline No & Uraian & $\begin{array}{c}\text { Total Biaya Produksi } \\
\text { Rp/Proses }\end{array}$ \\
\hline 1 & Biaya Tetap & 115.165 \\
2 & Biaya Variabel & 1.935 .547 \\
\hline Jumlah & & 2.050 .712 \\
\hline
\end{tabular}

Sumber: Olahan Data Primer 2019.

Jumlah total biaya produksi diperoleh dari penjumlahan total biaya tetap yaitu $\mathrm{Rp} 115.165$ /proses produksi ditambah dengan total biaya variabel yaitu Rp 1.935.547/proses produksi sehingga diperoleh total biaya produksi dalam usaha tersebut adalah Rp 2.050.712/proses produksi.

\section{B. Biaya Tetap Usaha Pengolahan Ikan Belida Menjadi Kerupuk}

Biaya tetap (fixed cost) merupakan biaya yang tidak habis dalam satu kali proses produksi dan jumlah dari biaya tetap tersebut tidak mempengaruhi jumlah produksi, seperti biaya sewa tempat usaha dan penyusutan alat, dengan biaya sewa tempat usaha.

Tabel 3. Total Biaya Tetap pada pembuatan kerupuk ikan belida.

\begin{tabular}{ccr}
\hline No & Uraian & $\begin{array}{c}\text { Biaya Tetap } \\
\text { Rp/Proses }\end{array}$ \\
\hline 1 & Biaya Sewa Tempat & 83.333 \\
2 & Biaya Penyusutan Alat & 31.832 \\
\hline Jumlah & & 115.165 \\
\hline
\end{tabular}

Sumber: Olahan Data Primer 2019.

Jumlah total biaya tetap diperoleh dari penjumlahan biaya sewa tempat yaitu Rp 83.333 /proses produksi ditambah dengan biaya penyusutan alat yaitu $\quad \mathrm{Rp}$ 31.832 /proses produksi sehingga diperoleh total biaya tetap dalam usaha tersebut adalah Rp 115.165/proses produksi.

\section{Biaya Variabel Usaha Pengolahan Ikan Belida Menjadi Kerupuk}

Biaya variabel (variabel cost) merupakan biaya yang dapat habis dalam satu kali proses produksi dan jumlahnya mempengaruhi jumlah produksi, seperti biaya bahan baku dan biaya tenaga kerja.

Tabel 4. Biaya Variabel pada pembuatan kerupuk ikan belida.

\begin{tabular}{clr}
\hline No & Uraian & $\begin{array}{c}\text { Biaya Variabel } \\
\text { Rp/Proses }\end{array}$ \\
\hline 1 & Biaya Bahan Baku & 1.701 .016 \\
2 & Biaya Tenaga Kerja & 234.531
\end{tabular}

\begin{tabular}{ll}
\hline Jumlah & 1.935 .547 \\
\hline Sumber: Olahan Data Primer 2019. &
\end{tabular}

Jumlah total biaya variabel diperoleh dari penjumlahan biaya bahan baku yaitu ikan belida sebagai bahan baku utama beserta bahan-bahan pendukung seperti sagu tani, susu bubuk, garam halus, gula dan telur bebek. Dari $3 \mathrm{~kg}$ ikan belida dan bahanbahan tambahan tersebut dapat menghasilan $6 \mathrm{~kg}$ kerupuk, ikan belida sendiri didapat dari pengepul yang berasal dari daerah OKI yang menampung tangkapan para pemancing ikan belida dari sungai-sungai besar di daerah tersebut. Ikan belida termasuk ikan yang susah didapatkan, oleh karena itu tidak setiap hari responden melakukan produksi kerupuk ikan belida. Jumlah biaya saprodi dari pembelian bahan-bahan baku tersebut yaitu Rp 1.701.016/proses produksi, ditambah dengan biaya tenaga kerja yang berasal dari masyarakat sekitar dan keluarga yaitu Rp 234.531 /proses produksi sehingga diperoleh total biaya tetap dalam usaha tersebut adalah Rp 1.935.547/proses produksi.

\section{Produksi, Penerimaan, dan Pendapatan Usaha Pengolahan Kerupuk Ikan Belida}

Menurut Suratiyah (2006), penerimaan merupakan nilai produk total yang dapat dihasilkan dalam sebuah usaha dan pada jarak tertentu. Sedangkan pendapatan merupakan selisih antara jumlah penerimaan dan seluruh biaya produksi. Adapun uraian dari penerimaan dan pendapatan yang diperoleh responden dalam usaha pengolahan kerupu ikan belida di Kelurahan Kemalaraja dalam satu kali proses produksi dapat dilihat pada table berikut

Tabel 5. Penerimaan dan Pendapatan pada pembuatan kerupuk ikan belida.

\begin{tabular}{|c|c|c|c|c|c|c|}
\hline No & Uraian & Satuan & Proses 1 & Proses 2 & Proses 3 & Rata-rata/Proses \\
\hline 1 & $\begin{array}{l}\text { Kebutuhan } \\
\text { Ikan Belida }\end{array}$ & $\mathrm{Kg}$ & 3 & 6 & 9 & \\
\hline 2 & $\begin{array}{l}\text { Toal Bahann } \\
\text { Baku } \\
\text { Produksi }\end{array}$ & $\mathrm{Kg}$ & 8,61 & 16,734 & 25,101 & $\begin{array}{r}6 \\
16,815\end{array}$ \\
\hline 3 & $\begin{array}{l}\text { Kerupuk } \\
\text { Produksi }\end{array}$ & $\mathrm{Kg}$ & 6 & 12 & 18 & 12 \\
\hline 4 & $\begin{array}{l}\text { (Kemasan) } \\
\text { Harga Jual }\end{array}$ & Ons & 60 & 120 & 180 & 120 \\
\hline 5 & (Kemasan) & Ons & 25.000 & 22.500 & 20.000 & 22.500 \\
\hline 6 & & $P$ & 100.000 & 2.700 .000 & 3.600 .000 & 2.600 .000 \\
\hline 7 & $\begin{array}{l}\text { Biaya } \\
\text { Produksi }\end{array}$ & $\mathrm{Rp}$ & 1.218 .485 & 2.082 .743 & 2.850 .908 & 2.050 .712 \\
\hline 8 & Pendapatan & $\mathrm{Rp}$ & 281.515 & 617.257 & 749.092 & 549.288 \\
\hline
\end{tabular}

Sumber: Olahan Data Primer 2019.

Dalam pengolahan ikan belida menjadi kerupuk responden melakukan produksi dengan takaran resep, dalam sekali produksi responden dapat mengolah satu sampai tiga resep olahan, yaitu dalam satu resep terdiri dari $3 \mathrm{~kg}$ ikan belida, $5 \mathrm{~kg}$ sagu beserta bahan-bahan lainya. Karena dalam produksinya responden dapat selalu mengolah satu resep atau lebih, dalam hal ini penulis melakukan penghitungan dengan rata-rata resep. Dalam satu kali produksi responden 
membutuhkan ikan belida rata-rata $6 \mathrm{Kg} /$ proses produksi, dari $6 \mathrm{Kg}$ ikan belida menghasilkan produksi rata-rata $12 \mathrm{Kg}$ dan dikemas kedalam plastik dengan berat masing-masing 100 gr kerupuk, dengan harga jual Rp 22.500 maka diperoleh penerimaan rata-rata yaitu sebesar $\mathrm{Rp} \mathrm{2.600.000/rata-rata} \mathrm{proses} \mathrm{produksi,}$ dengan mengurangkan penerimaan sebesar Rp 2.600.000 / rata-rata proses produksi dengan rata-rata biaya produksi sebesar Rp 2.050.712/rata-rata proses produksi maka diperoleh rata-rata pendapatan sebesar Rp 549.288/ rata-rata proses produksi.

\section{E. Nilai Tambah Usaha Pengolahan Ikan belida Menjadi Kerupuk Ikan belida}

Nilai tambah adalah selisih antara nilai komoditi yang mendapat perlakuan pada tahap tertentu dikurangi dengan nilai korbanan yang digunakan selama proses produksi berlangsung. Nilai tambah yang dapat dihasilkan dalam usaha pengolahan kerupuk ikan belida di Kelurahan Kemalaraja adalah Rp. $\quad 107.389 \quad / \mathrm{Kg} /$ Rata-tata proses produksi. Berdasarkan hal tersebut maka usaha pengolahan kerupuk ikan belida di Kelurahan Kemalaraja menguntungkan.

Tabel 6. Nilai Tambah pada pembuatan kerupuk ikan belida

\begin{tabular}{|c|c|c|c|c|c|c|}
\hline No & Uraian & Satuan & Proses 1 & Proses 2 & Proses 3 & $\begin{array}{c}\text { Rata- } \\
\text { rata/Proses }\end{array}$ \\
\hline & Kebutuhan & & & & & \\
\hline 1 & $\begin{array}{l}\text { Ikan Belida } \\
\text { Toal Bahan }\end{array}$ & $\mathrm{Kg}$ & 3 & 6 & 9 & 6 \\
\hline 2 & $\begin{array}{l}\text { Balas } \\
\text { Produksi }\end{array}$ & $\mathrm{Kg}$ & 8,61 & 16,734 & 25,101 & 16,815 \\
\hline 3 & $\begin{array}{l}\text { Kerupuk } \\
\text { Produksi }\end{array}$ & $\mathrm{Kg}$ & 6 & 12 & 18 & 12 \\
\hline 4 & (Kemasan) & Ons & 60 & 120 & 180 & 120 \\
\hline 5 & (Kemasan) & Ons & 25.000 & 22.500 & 20.000 & 22.500 \\
\hline 6 & $\begin{array}{l}\text { Penerimaan } \\
\text { Biaya }\end{array}$ & $R p$ & 1.500 .000 & 2.700 .000 & 3.600 .000 & 2.600 .000 \\
\hline 7 & Produksi & $R p$ & 1.218 .485 & 2.082 .743 & 2.850 .908 & 2.050 .712 \\
\hline 8 & $\begin{array}{l}\text { Pendapatan } \\
\text { Tenaga Kerja }\end{array}$ & $R p$ & 281.515 & 617.257 & 749.092 & 549.288 \\
\hline 9 & Kelurga & $\mathrm{Rp}$ & 53.438 & 77.188 & 103.906 & 78177 \\
\hline 10 & Biaya Antara & $\mathrm{Rp}$ & 1.165 .048 & 2.005 .556 & 2.747 .001 & 1.972 .535 \\
\hline \multirow[t]{2}{*}{11} & Nilai Tambah & Rp/proses & 334.952 & 694.444 & 852.999 & 627.465 \\
\hline & & Rp/kg & 38.903 & 41.499 & 33.983 & 38.128 \\
\hline
\end{tabular}

Sumber: Olahan Data Primer 2019.

Dalam satu kali produksi responden membutuhkan ikan belida rata-rata $6 \mathrm{Kg} /$ proses produksi, dari $6 \mathrm{Kg}$ ikan belida menghasilkan produksi rata-rata $12 \mathrm{Kg}$ dan dikemas kedalam plastik dengan berat masing-masing 100 gr kerupuk, dengan harga jual Rp 22.500 diperoleh penerimaan penerimaan rata-rata yaitu sebesar Rp 2.600.000 /proses produksi, pendapaatn diperoleh dari mengurangkan penerimaan sebesar $\mathrm{Rp}$ 2.600.000/proses produksi dengan rata-biaya produksi sebesar Rp 2.050.712/proses produksi maka diperoleh rata-rata pendapatan sebesar $\mathrm{Rp}$ 549.288/proses produksi.

Karena tenaga kerja tidak hanya dikerjakan dari luar keluarga (upahan) dan juga dierjakan oleh anggota keluarga yaitu sebagai control quality, maka tenaga kerja keluaraga Rp78.177, maka diperoleh biaya antara yaitu Rp1.972.535, dengan biaya antara sebesar Rp 1.972.535 maka diperoleh nilai tambah $\mathrm{Rp} /$ rata-rata proses yaitu Rp 627.465 dan nilai tambah $\mathrm{Rp} / \mathrm{Kg}$ yaitu Rp38.128.

\section{V.KESIMPULAN DAN SARAN}

\section{A. Kesimpulan}

Berdasarkan hasil penelitian ini, maka kesimpulan yang dapat dimbil adalah sebagai berikut :

1. Pendapatan yang diperoleh dalam usaha pengolahan ikan belida menjadi kerupuk di Kelurahan Kemalaraja Kecamatan Baturaja Timur Kabupaten OKU adalah Rp 549.288 /rata-rata Produksi.

2. Sedangkan nilai tambah yang dihasilkan dalam usaha pengolahan ikan belida menjadi kerupuk di Kelurahan Kemalaraja Kecamatan Baturaja Timur Kabupaten OKU adalah Rp 627.465 /rata-rata Produksi, dan nilai tambah per Kg yaitu Rp38.128.

\section{B. Saran}

Adapun saran yang dapat direkomendasikan berdasarkan hasil penelitian ini adalah sebagai berikut :

1. Hendaknya pengelola ikan belida menjadi kerupuk agar tetap menjaga dan memperhatikan kualitas produk dengan quality control yang baik

2. Untuk memenuhi kebutuhan bahan baku hendaknya pengelola ikan belida menjadi kerupuk memperbanyak mitra dengan pemasok ikan agar produksi tidak terhambat.

\section{DAFTAR PUSTAKA}

Frasetiandy, D. 2009. Menakar Dampak Sosial Perkebunan Swait. Diakses pada 4 November 2010. (http://www.walhi.or.id, diakses 4 November 2010).

Anonim. 2010. Majalah Warta Pasar Ikan Edisi Oktober.

Anonim. 2005. Jurnal Pengolahan Kerupuk Ikan Belida. Anonim. 2018. Mengenal Sekilas Chitala Lopis, si Langka yang Dilindungi.

Arifudin, R. Ikan Belida Hewan Langka yang Dilindungi. BPTP. Palembang.

Arikunto, S. 2002. Metrodologi Penelitian. Penerbit PT. Rineka Cipta. Jakarta.

Arsyad, L. 2003. Ekonomi Manajerial. Edisi Kelima. Balai Pustaka. Yogyakarta.

Bleeker. 1851. Chitala hyposelonatus.

Downwy, W.D. dan Erickson, S.P. 2004. Manajemen Agribisnis. Erlangga. Jakarta.

Faizul.2009. Ekonomi Makro. Graha Ilmu. Yogyakarta Fitriah M,. 2015. Analisis Nilai Tambah Penjualan Jamur Tiram. Skripsi STIPER Belitang, (tidak dipublikasikan) 
Hermanto, F. 2010. Ilmu Usaha Tani. Penebar Swadaya. Jakarta

oersan. 2003. Teori Ekonomi Mikro. Selemba Empat. Jakarta.

Kastasapoetra. 2006. Manajemen Pertanian Agribisnis. P.T Gramedia. Jakarta.

Manullang. 2008. Dasar-Dasar Manajemen. Yogyakarta: BPFE-Yogyakarta.

Marimin, dan Magfiroh N. 2010. Aplikasi Teknis Pengambilan keputusan dalam Manajemen Rntai Pasok. Bogor.

Mubaryoto. 2001. Pengantar Ekonomi Pertanian LP3ES. Jakarta.

Mulyadi. 2007. Akuntansi Biaya Edisi Kelima. Graha Ilmu. Yogyakarta.

Saragih, B. 2001. Suara dari Bogor Membangun Sistem Agribisnis. Yayasan USES Bekerjasama dengan SUCOFINDO. Bogor.
Sjarkowi, dan Marwan,S. 2004 Manajemen Pembangunan Agribisnis. CV Baldad

Soekartawi. 2001. Prinsip Dasar Komunikasi Pertanian. UI Press. Jakarta

Soekartawi. 2002. Analisis Usaha Tani. Jakarta: Universitas Indonesia.

Soekartawi. 2005. Agroindustr Dalam Perspektif Sosial Ekonomi. Raja Grafindo Persada. Jakarta.

Sugiyono. 2012. Mertode Penelitian Kuantitatif Kualitatif dan R\&D. Bandung: Alfabeta.

Wastono. 2004. Materi Integritas Sains. Jakarta: Depdiknas.

Yudi, AB. 2010. Agribisnis terintegrasi Hulu dan Hilir. CV Muara ndah. Bandung 